\title{
THE EARLY HISTORY OF ANAESTHESIA IN CANADA: THE INTRODUCTION OF ETHER TO UPPER CANADA, 1847
}

\author{
David J. STEward*
}

\begin{abstract}
INTRODUCTION
Althovgh ClaRK administered ether for a dental extraction in January $1842^{1}$ and Long used it to produce anaesthesia for surgical operations in March $1842,{ }^{2}$ the use of this agent did not become widespread until more than four years later. It was following a demonstration at the Massachusetts General Hospital on October 16, 1846, when William Morton administered ether ("Letheon") to Gilbert Abbott for the excision of a neck tumour by John C. Warren, Professor of Surgery, that the news of surgical operations performed during insensibility spread. Reports of the use of ether vapour appeared from the eastern United States, ${ }^{3}$ and on December 19 , 1846, it was first used in both London, England, ${ }^{4}$ and Dumfries, Scotland. ${ }^{5}$

In Canada, the earliest accounts of the use of ether originate in Quebec. Dr. James Douglas of Quebec City used it during amputation of toes ${ }^{6}$ some time before February 20, 1847, on which date Mr. Webster, a dentist, administered ether while Dr. Nelson of Montreal, assisted by his son Horace, removed a tumour from a woman's thigh. ${ }^{7}$ Both predated the achievement of Dr. Edward Worthington of Sherbrooke, who claimed" to have performed the "First capital operation in Canada under the influence of sulphuric ether ... on 14 March 1847".

The early use of ether in Ontario is not documented in the medical literature. No medical journals were published in the region until April $1851,{ }^{9}$ when The Upper Canada Journal of Medical, Surgical and Physical Sciences was inaugurated. This journal, which survived less than four years (until September 1854), included no mention of the early use of ether in this area.

It has been stated ${ }^{10}$ that the first recorded use of anaesthesia in Ontario was with chloroform, given by Dr. Duncan Campbell, of Niagara, on May 31, 1848. However, since news of the application of sulphuric ether to produce insensibility during surgical operations had travelled so rapidly from Boston to Europe and Quebec, I considered it unlikely that this was ignored in Upper Canada. As there were no contemporary medical journals, I reviewed the available Upper Canada newspapers published between October 16, 1846, and the end of June, 1847, and from these I compiled a history of ether in what is now Ontario.
\end{abstract}

\section{The News Arrives From Boston}

On Wednesday, December 23, 1846, news of Morton's achievement appeared on

-Department of Anaesthesia, University of Toronto, and The Hospital for Sick Children, Toronto.

Mailing Address: Dr. D.J. Steward, Department of Anaesthesia, The Hospital for Sick Children, 555 University Avenue, Toronto, Ontario M5G 1 X8. 


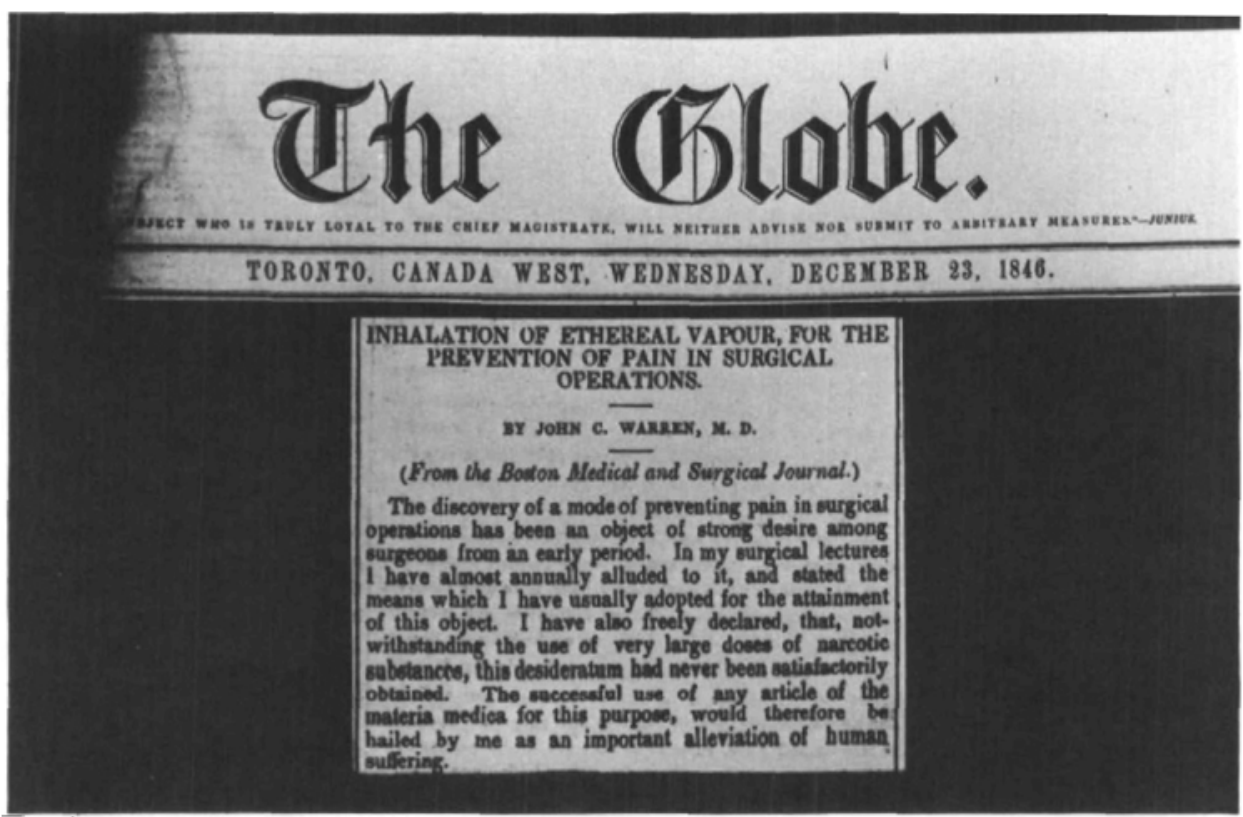

Ficure 1. Report of the use of ether in Boston in October, 1846; from The Globe, Toronto, December 23, 1846. (From the Archives of Ontario. Reproduced with kind permission of The Globe and Mail.)

the front page of The Globe, in Toronto (Fig. 1), in a report by John C. Warren published in the Boston Medical and Surgical Journal. Dr. Warren, whose story was dated December 3, 1846, went on to say: "About five weeks since, Dr. Morton, dentist of this city, informed me that he had invented an apparatus for the inhalation of vapour, the effect of which was to produce a state of total insensibility to pain ..."

There followed a detailed description of the use of ether vapour during several operations in Boston: "In all these cases there was a decided mitigation of pain ... All those who attended were, I think, satisfied of the efficacy of the application in preventing, or at least greatly diminishing, the suffering usual in such cases ..."

"Let me conclude by congratulating my professional brethren on the acquisition of a mode of mitigating human suffering, which may become a valuable agent in the hands of careful and well-instructed practitioners, even if it should not prove of such general application as the imagination of sanguine persons would lead them to anticipate."

The same report was printed in the Western Globe (London, Western and Huron District Advertiser) on Friday, December 25, and in the Toronto Patriot of Tuesday, December 29, 1846.

However, Brockville had received the news three weeks earlier: on December 3 , the date of Warren's report in the Boston Medical and Surgical Journal, the Brockville Recorder featured the following letter, from one "D.M.R."

\section{For the Commerctal Advertiser}

"Sirs, - I send you the last number of the Boston Medical and Surgical Journal, 
in which you will find the earliest professional notice of one of the most valuable discoveries of the age, as interesting to our common humanity, as it is to the science of practical surgery. - The Testimony here given is from Professor Bigelow, of Boston whose eminence as a teacher and practitioner is unsurpassed in the country. The operations performed in the Massachusetts General Hospital at Boston, upon patients rendered insensible to pain, by the new chemical agent referred to, have not only been under the writer's own eyes, but have had the scrutiny of such distinguished surgeons as Professor Warren \& Hayward of Boston, who seem to have been the operators.

"This novel and successful invention is due to the combined genius of Dr. Charles T. Johnson, a scientific chemist, and Dr. Morton, a professional dentist, both of Boston. The process and specific agent employed have been patented at home and abroad, with a view not merely to secure remuneration to the parties, but to the protection of the community against abuses to which this agency is liable. And should future experiments confirm the trials made in Boston, the discoverers will have merited the rewards due to public benefactors.

"You will observe that there is nothing in this process at all analogous to the fictions of Mesmerism, in-suspending nervous sensibility by metaphysical agency. On the contrary, physical causes, adequate to the production of the physical effects alleged to be produced, are apparent in the nature of the chemical agent avowedly employed. A preparation of alcoholic ether the preparation of which is at present only known to the inventors, is inhaled into the lungs of a patient until a patholstate simulating that of intoxication is induced, with the morbid indications which demonstrate the reality of the phenomena; viz. - unconsciousness and insensibility to pain.

"These morbid indications, furnishing as they do, physiological proofs, in the pupils of the eyes and abnormal action of the heart, of their physical sensation, cannot possibly be feigned. The absence of such changes, though vaunted by Mesmerism, is among the proofs of the deceptions and frauds of which popular credulity renders multitudes the dupes.

"I send you an article of Dr. Bigelow, in the belief that the insertion of the whole paper, or suitable extracts, will render a public service.

The "Commercial Advertiser" stated:

"Respectfully yours," D.M.R.

"The 'whole paper' would occupy more than two of our columns, which we cannot well spare; nor indeed is the reproduction of the whole at all necessary, as a large portion of it is occupied by notices of the effects produced by other agents inhaled or taken in the liquid form. We copy only those passages which relate specifically to the newly discovered agent."

The Chatham Gleaner, also, contained news of ether anaesthesia before the Toronto newspapers; on December 15, 1846, it reprinted the following item from the Buffalo Commercial Advertiser.

\footnotetext{
"My attempts to identify "D.M.R." have been unsuccessful, but the contents of his letter and the speed with which it arrived in Brockville (three weeks before the news was printed in Toronto) suggest that he may have been associated with Morton's attempts to patent and promote the use of "Letheon".
} 
"EXTRAORDINARY SURGICAL OPERATION. - By a railroad accident at Wenham, Mass., a young Irish girl was so much injured, as to render necessary the amputation of an arm. The Salem Register states that 'the operation was performed by Dr Pierson, accompanied by Dr Fisk, who administered to the sufferer, with perfect success, the new preparation lately made known by Dr Jackson, and Dr Morton, Dentist, of Boston, the inhalation of which produces insensibility to the pain of surgical operations. The unconsciousness of the girl continued undisturbed until near the close of the dressing, when she simply inquired what they were doing; but, with another inhalation immediately relapsed into insensibility; and upon coming to herself, supposed she had been dreaming.'

"The Register relates another accident which occurred on Saturday, in consequence of which, amputation of a leg was performed by the same process, with the same successful results. Cannot the marvels related to Magnetism, its power of rendering subjects insensible to pain, \&c. be accounted for by the inhalation of a similar preparation, dexterously administered. - Buffalo Commercial Advertiser."

\section{The Use of Ether in Upper Canada, 1847}

The first report I could find of surgery being performed under ether in Upper Canada was an article from the Cobourg Star, ${ }^{\circ}$ reprinted in the Christian Guardian (Toronto) on May 5, 1847:

"On Tuesday last (see footnotef) we saw George Goldstone, Esquire, Surgeon of this town administer ether to a patient previous to performing a very painful operation. The inhalation was only for a minute, when the patient became unconscious of pain and the operation was performed without drawing from her any signs of feeling. We understand that Mr. Goldstone has administered ether in many cases, and has not yet met with a single failure in rendering the patient unconscious of pain.

"In the simple matter of tooth drawing alone it is invaluable."

According to Canniff, ${ }^{11}$ Dr. George Goldstone "was born in Bath, England, January 25,1806 . He studied medicine at Edinburgh ... For some years he was surgeon on board an East Indian merchantman. He came to Canada about 1835 ... He practised in Cobourg and the surrounding country until 1862, when he retired and removed to Quebec." Also from Canniff, ${ }^{11}$ the words of an acquaintance of the subject: "The record of Dr. Goldstone's professional life in Canada was that of a pioneer doctor. He oftentimes was called at midnight in winter to visit patients many miles away, whose homes lay in the midst of forests far from neighbours or help of any kind, and far even from a beaten road. He frequently rode on horseback sixty miles a day, it being impossible to drive a carriage through the uncultivated country. He was on duty with the militia in the Rebellion of 1837 as surgeon

\footnotetext{
'Issues of the Cobourg Star for the last three months of 1846 and to the end of June 1847 are not available.

f"Tuesday last" most probably referred to Tuesday, April 27, 1847, if we allow one week for the news item from the Cobourg Star to be picked up and reprinted by the Christian Guardian in Toronto. The stage-coach between Cobourg and Toronto ran six times a week each way and took approximately ten hours - "from Cobourg to Toronto by day light".13
} 
to the Northumberland militia. His work during the cholera of 1840 was of a most difficult and painful nature. He was a noted and very successful surgeon".

Thus we can picture Dr. Goldstone as a pioneer doctor, practising a wide range of medicine but with a special interest in surgery. He was almost 41 years old when he read in December, 1846, of the use of ether to perform painless surgery, and within 4 months he was using this agent regularly in his varied city and rural practice." (Thus the statement: "We understand that Dr. Goldstone has administered ether in many cases ... In the simple matter of tooth drawing alone it is invaluable.")

George Goldstone was one of five or six doctors who practised in Cobourg during the 1840s. ${ }^{12}$ Unlike many of his colleagues, he apparently did not participate extensively in municipal affairs, but was president of the Cricket Club in $1846{ }^{13}$ He lived in the east end of Cobourg - "which was always the more exclusive and aristocratic"; ${ }^{13}$ his house still stands, but has been extensively remodelled. ${ }^{12} \mathrm{Dr}$. Goldstone died in Quebec in December 1872, and was buried in St. Peter's churchyard in Cobourg.

The second reference (and the only other one I could find) to the use of ether in Upper Canada during the first six months of 1847 is in the Brockville Recorder for May 13, 1847; this news item was carried in The Globe, in Toronto, on May 22.

"On Saturday last, (8th May, 1847) Dr. Reynolds of this Town, assisted by Dr. Scott, of Prescott, performed an operation upon a son of Dunham Jones, Esq. of Augusta, while under the influence of ethereal vapour. The patient, a lad of 14, was nearly five minutes under the influence, and although subjected to an operation, otherwise of an exceedingly painful nature, he appeared quite unconscious of any pain or suffering. The fleshy substance of the thigh was laid open for about four inches, down to the bone, and in doing so it was necessary to dissect round several vessels to avoid wounding them. The surface of the bone itself was scraped with an instrument but not the slightest pain was evinced. The patient described the sensation as that of a confused dream, he said he felt a numbness extending gradually from the toes, upwards, and this numb sensation continued for half an hour after the operation - the pupil of the eye was dilated and fixed, the breathing accelerated and the pulse slightly quickened while under the influence and when he recovered, the feeling and appearance was very similar to that of a half intoxicated person. - This effect continued for several hours after the operation. The ether was administered by Mr. Blodgett, of Ogdensburgh [now Ogdensburg; author], from an apparatus partly of his own contrivance, and which appears to be well adapted for the purpose."

Thomas Reynolds was born in Brockville in 1820 and at the age of 16 went to Montreal to study medicine with Dr. Stephenson. Three years later he entered the University of Edinburgh to complete his studies. He practised first in Williamsburg (now Morrisburgh), moving to Brockville in 1846. Reynolds took a great interest in all scientific and education matters and, in addition to writing articles for publication in medical journals, "contributed to" the Canadian Institute and the Smithsonian Institution. ${ }^{11}$ (None of these contributions appears to relate to the use of ether.)

William Scott did his medical training in Dublin, Ireland, and came to Canada in 1814. By 1834 he was "the best known Doctor in that part of the country. His practice extended over a large district, usually from Matilda to Brockville ..."11 


\section{"Wonders wlll Niver Cease."}

\section{SDRGICAL OIERATTOHS CAN IE ERRO? MEU WITHOUT IAIN.}

DR. AMRLER \& BLODGETT, - Would respectfully inform the inhabitante of this place and vicinity that they have secured the right of using DOCT. MORTON'S "LETIIE. AN GAS," and that they are now prepared to administer it in the safest manner. They will uso it in all painful operations in DE.vTaL. SURGE. $\mathbf{R} \mathbf{x}$, when required, and also administer it in ail surgical operations attended with pain, when re. quesiod by residen: Physiciats. May 3, 1817 . 21-11

Ficure 2. Advertisement that appeared in the St. Lawrence Republican, Ogdensburgh, New York, May 3, 1847. (From the Archives of the Ogdensburg Public Library, with kind permission.)

Samuel Blodgett was a dentist, practising in both Ogdensburg and the Brockville area. He was born in 1822, and in 1846 at the age of 24 went to work in partnership with a Dr. Ambler "in the practice of dentistry" ${ }^{15}$ Their office was on State Street in Ogdensburg - "occasionally visiting other places in the vicinity".

On May 3, 1847, Drs. Ambler and Blodgett placed an advertisement in the St. Lawrence Republican (Fig. 2), advising their intention to use Morton's "Lethean Gas".

During the same period the partners were advertising regularly in the Brockville Recorder as follows.

\section{To My Patrons and Friends}

"Having made arrangements for spending the ensuing Winter at the South, and being desirous of some one to whom I could recommend my friends during my absence, I have induced Dr. S. S. BLODGETT to locate himself in OGDENSBURGH, in the practice of his profession, and have formed a partnership with him for that purpose.

"The flattering Testimonials which he brings from the President of Castleton Medical College, and others; the favorable opportunity he has had for seeing practice and doing it, and from the intimate personal acquaintance I have had with Dr. B. (he having spent the past season with me in my office, assisting me in all 
my operations ), enables me to speak with entire confidence of his skill and gentlemanly deportment.

"To my friends who have heretofore favored me with their patronage, I return my most cordial acknowledgments, and am happy in being able to refer them to Dr. Blodgett, with the assurance, that his operations will be carefully and skillfully performed during my absence.

"Early next season I expect to return and spend the summer, and shall be happy to see my old friends."

D.C. AMBLER

Drs. Reynolds and Scott were obviously among the first to engage Dr. Blodgett to administer ether to their patients, and Dr. Blodgett, a dentist, was among the first to use ether in Ontario.

Samuel Blodgett continued to practice dentistry and to administer "Lethean" in the St. Lawrence region on both sides of the border (by the end of 1848 he was offering chloroform, instead ${ }^{16}$ ) until January 1849 , when he died; he was only 26 years old. "On the Saturday previous to his death he went to Brockville with the purpose of answering a professional call: but only reached there to be taken to the sick bed, whence he was never to rise. The exposure consequent on the journey, during a cold day, probably induced the attack, which soon manifested itself in extreme biliary derangement and terminating in congestion of the brain." ${ }^{14}$

\section{Conclusion}

It is apparent that, despite the earlier use of ether by a country practitioner (Crawford Long) and dentists (William Clark and Horace Wells), the influence of a pair of distinguished surgeons (John C. Warren and Henry Bigelow) was required to promote the widespread use of ether following William Morton's demonstration of its efficacy at the Massachusetts General Hospital. The accounts that Drs. Warren and Bigelow wrote for the Boston Medical and Surgical Journal were widely reported in many countries. Dr. Bigelow's father, Professor Jacob Bigelow, wrote a personal letter to a friend in England, Dr. Francis Boott, telling him of the discovery. Two days after receiving this letter, Dr. Boott was present when ether was first administered in England (on December 19, 1846), and two days after this Robert Liston used ether for a leg amputation at University College Hospital in London. Thus the future of surgical anaesthesia in England was assured. The abortive attempts by Morton to conceal the nature of the anaesthetic agent and to patent the process of its application little delayed the spread of the use of ether.

The news of ether anaesthesia was received in Upper Canada during December 1846. In fact, the country practitioners of Brockville or Chatham heard of this discovery before Francis Boott or Robert Liston in England.

Upper Canada in the 1840 s was a country of pioneers: country doctors were accustomed to managing all aspects of medical care, so it is not surprising that it was these practitioners who read of ether anaesthesia and were among the first 


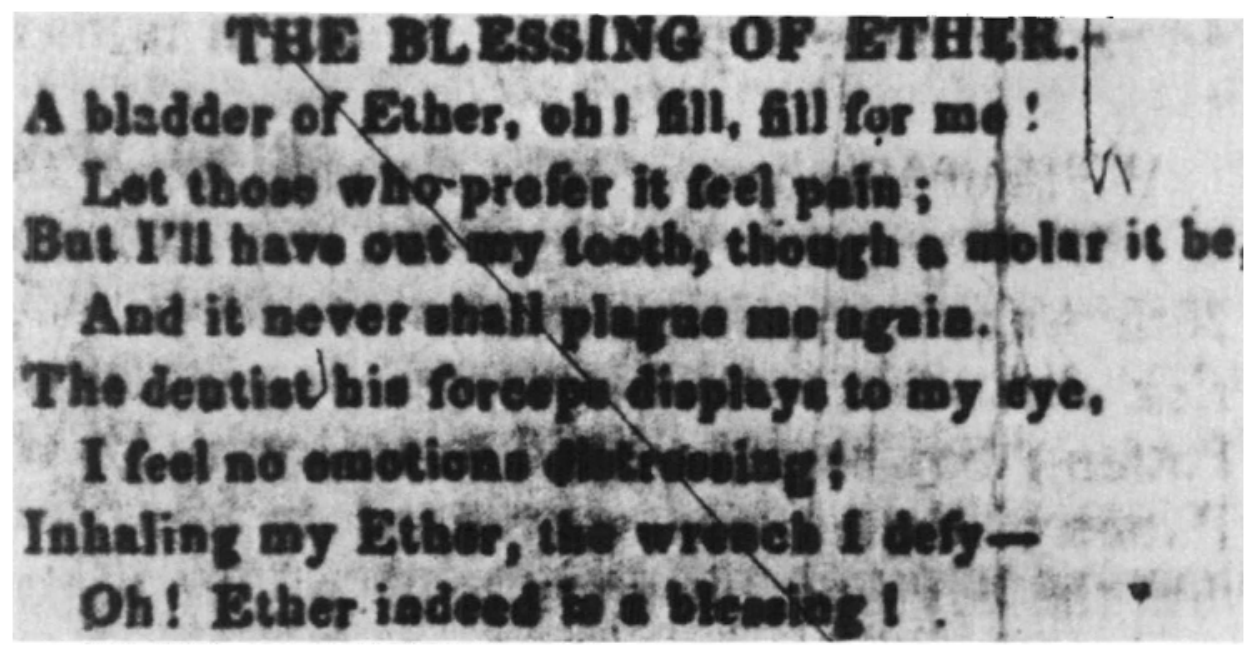

Figures 3. From the Chatham Gleaner, Chatham, Ont., May 25, 1847. (From the Archives of Chatham Public Library, with kind permission.)

to apply it. The use of ether for tooth extraction and surgical operations was probably widespread throughout rural Upper Canada within six months of Morton's original demonstration - as illustrated in Fig. 3, an excerpt from the Chatham Gleaner of Tuesday, May 25, 1847.

\section{RÉSUMÉ}

La découverte et la pratique de l'anesthésie à l'éther par d'obscurs praticiens de campagne (Crawford Long, médecin, et William Clark et Horace Wells, dentistes) étaient en passe de demeurer ignorées et il aura fallu tout le poids de l'influence combinée des docteurs Warren et Bigelow, tous deux de grande renommée, pour permettre à l'anesthésie à l'éther de faire une entrée remarquée dans le monde médical, à la suite de la démonstration de Williám Morton.

Les comptes rendus originaux des docteurs Warren et Bigelow écrits pour le Boston Medical and Surgical Journal ont connu dans plusieurs pays une très large diffusion, de sorte que dès le 19 décembre 1846, soit à peine deux mois après l'événement de Boston, on effectuait en Angleterre une première anesthésie à l'éther.

Il semble que la nouvelle de la découverte soit parvenue ici en Haut Canada au cours de décembre 1846. On croit même pouvoir affirmer que des médecins de campagne de la région de Brockville ou de Chatham étaient mếme au fait de cette découverte avant qu'elle ne parvienne en Angleterre. Le Haut Canada à cette époque était un pays de pionniers, les médecins, particulièrement en campagne, exerçaient sur tous les fronts et il est peu suprenant que mis au fait de l'anesthésie à

- Note that the Toronto newspapers were reporting the use of ether by a country doctor (Goldstone) and a dentist (Blodgett), with no mention of the use of this agent by city surgeons. Indeed, as late as November 6, 1847, in the Hamilton Spectator a surgeon - "Dr. Freeman, late of New Orleans" - was advertising his surgical practice with no mention of anaesthesia. 
l'éther, ils aient été les premiers à l'utiliser. Moins de six mois après la démonstration originale par Morton, il est permis de croire que l'on utilisait couramment l'anesthésie à l'éther pour des opérations chirurgicales et des extractions dentaires dans tout le territoire du Haut Canada, comme en fait foi cet extrait du Chatham Gleaner daté du 25 mai 1847 (fig. 3).

\section{ACKNOWLEDGEMENTS}

The author is indebted to Dr. D.E. Mikel of Cobourg, Ontario, and Mrs. P.E. Boyesin, City Archivist, Ogdensburg, New York, and the Medical Publications Department, The Hospital for Sick Children, for assistance in the preparation of this manuscript.

\section{REFERENCES}

1. KEYs, T.E. The history of surgical anesthesia. New York, N.Y., Schuman's, pp. 21-22 (1945).

2. LONG, C.W. An account of the first use of sulphuric ether by inhalation as an anaesthetic in surgical operations. South. Med. Surg. J. 5: 705-713 (1849).

3. Extraordinary surgical operation: Buffalo Commercial Advertiser; reported in the Chatham Gleaner, December 15, 1846.

4. Boort, F. Letter to the Editor. Lancet 1: 8 (1847).

5. BAILLIE, T.W. The first European trial of anaesthetic ether - the Dumfries claim. Br. J. Anaes. 37: 952 (1965).

6. Editorial note: employment of sulphuric ether vapor in Montreal, Quebec, and Sherbrooke. Br. Am. J. Med. Phys. Sci. 2: 338 (April 1847)

7. The Pilot, Montreal (Friday, February 26, 1847).

8. Worthington, E.D. Reminescenses of Student Life \& Practice. Sherbrooke, Que. (1897).

9. MACDERMOT, H.E. A bibliography of Canadian medical periodicals, with annotations. Montreal, Renouf, 1934.

10. Colbeck, W.K. The first record of an anaesthetic in Ontario. Can. Med. Assoc. J. 32: 84-85 (1935).

11. CANIFF, W. The medical profession in Upper Canada, 1783-1850, Toronto, Briggs (1894).

12. Mikel, D.E. Personal communication (August 1976).

13. Guilzet, E.C. Cobourg, 1798-1948. Oshawa, Ont., Goodfellow (1948).

14. St. Lawrence Republican, Ogdensburg, New York (January 16, 1849).

15. Ibid. (April 20, 1847).

16. Ibid. (January 2, 1849). 